\title{
A constituição do estado moderno: do ideal de liberdade para o Princípio da dignidade da pessoa humana
}

The constitution of the modern state: the ideal of freedom for the principle of human dignity

\author{
Prof. Esp. Cássio Marcelo Mochi ${ }^{1}$
}

\begin{abstract}
Resumo
Apresenta a possibilidade de uma melhor compreensão acerca dos elementos que permitiram a formação do Estado Moderno, e suas relações coma restrição à liberdade, acentuada posteriormente pelo capitalismo, que substitui um ideal, e como tal, amplo e fundamentado em modelos, cujo espelho é a antiguidade clássica, pela perspectiva de direitos que garantam a dignidade humana, manifestando não mais como um ideal a ser conquistado, mas um mínimo a ser garantido, muito mais no campo da formalidade, da abstração, do que da prática efetiva e real das ações garantidoras desta dignidade. 0 Estado Moderno e capitalista, substitui um ideal, por uma formalidade utópica, ao qual ele mesmo cria, mas estabelece limites intransponíveis para que este seja conquistado, e a transforma num bem material, pois a liberdade agora será associada à condição de consumo.
\end{abstract}

Palavras Chave: Estado; Constituição; Direito; Política; Liberdade.

\begin{abstract}
Presents the possibility of a better understanding of the factors which enabled the formation of the modern State and its relations coma restriction of freedom, later accentuated by capitalism, which replaces an ideal, and as such, and based on comprehensive models, which is the mirror classical antiquity, from the perspective of rights guaranteeing human dignity, expressing no more as an ideal to be striven for, but a minimum to be guaranteed, much in the field of formality, abstraction, than the actual practice and real actions that guarantee this dignity. The modern state and capitalist, an ideal substitute for a utopian formality, which he himself creates, but it sets limits for this to be conquered, and transformed into a material good, because freedom will now be associated with the condition of consumption.
\end{abstract}

Keywords: State, Constitution, Law, Politics, Freedom.

\footnotetext{
${ }^{1}$ Professor de Filosofia, Especialista em Docência no Ensino Superior, Acadêmico da Universidade Estadual de Londrina, no Curso de Pós Graduação em Direito Constitucional, promovido pelo Departamento de Direito no ano de 2006.
}

Revista de DiReito Púbuco, LONDRINA, V. 4, N. 1, P. 1-26, JAN/ABR. 2009. 


\section{Introdução}

O Estado Moderno ao mesmo tempo em que possibilitou avanços no mundo da ciência, e das relações entre os Estados, trouxe consigo uma série de problemas sociais resultantes da sua estrutura interna, que nos dias de hoje, se manifestam eminentemente capitalista, pois a queda do Muro de Berlim, se não extinguiu totalmente a possibilidade da existência de um socialismo real, aumentou de forma abissal a sua execução nos momentos atuais, mas também tornou ainda mais evidente o não cumprimento das promessas do capitalismo, e o aumento da desigualdade de condições e perspectivas da construção de um Estado ideal.

$\mathrm{Na}$ formação do Estado Moderno, na acepção da palavra Estado tal qual entendemos nos dias atuais, que segundo Skinner (1996, p. 10), tem a sua origem no século XVI, ao menos na França e na Inglaterra, temos a Constituição, ou Carta Magna, como um dos elementos jurídicos que irão definir a estrutura do Estado como um todo, e apresentar os fundamentos de sua legitimidade. Para Canotilho (2003, p. 52) a Constituição M oderna é um "documento escrito no qual se declaram às liberdades e os direitos e se fixam os limites do poder político".

A tríade liberdade-direito-poder, parece-nos ser comum a maioria das definições do que vem a ser uma Constituição no Estado Moderno. Será necessário buscar uma compreensão de qual liberdade o mundo moderno estabelece como referencial, e qual a sua real dimensão dentro das constituições, e se estas ampliam ou reduzem este conceito, para se adequarem às exigências do liberalismo que originou o mundo moderno, e buscou garantias jurídicas para a sua permanência, estabelecendo a propriedade como elemento central para a sua fundamentação.

Para compreendermos a formação do Estado Moderno, será preciso analisar, mesmo que de modo sintético, a passagem da medievalidade para a modernidade, tendo o Renascimento Italiano, como um período de transição e que muito contribui para o estabelecimento do mundo jurídico, tal qual temos nos dias atuais. Segundo Skinner, foi a necessidade da liberdade de se auto-governar que impeliu as cidades no norte da Itália, já no século XII a buscar uma forma de "repúblicas independentes; cada uma delas era governada 'pela vontade de cônsules mais que de príncipes'" (1996, p. 25). Cada cidade possuía uma estrutura própria para a administração de seus interesses, e mesmo que de 


\section{A constituição do estado moderno: do ideal de liberdade para o Princípio da dignidade da pessoa humana}

forma limitada, constituía o seu próprio corpo de leis, estabelecendo as condições mínimas, mas suficientes, para garantir a coesão social e jurídica dos seus cidadãos.

No entanto, ao analisarmos a história da liberdade, quase que de forma inevitável associamo-la com as condições de produção e consumo, ou seja, o homem é livre enquanto tem possibilidades de se tornar um agente de consumo, mas quanto à produção, pode ter um alto grau de liberdade quando se encontra no ápice da hierarquia produtiva, em outras palavras, quando possuía a posse da propriedade que são os meios materiais necessários à produção. Mas também pode situar-se internamente nesta cadeia de produção, como aquele que vende, de forma miserável, ou próximo desta, a sua força de produção, no entanto, quando os fatores levam a uma eminência de discórdia e rompimento destas relações, o mundo do direito nos apresenta a norma jurídica como forma de contenção e legalidade da existência do desequilíbrio social. A liberdade se reduz a perspectivas formais e de interpretações vagas e contingênciais, inclusive de ordem orçamentária e ideológicas, o homem se desconecta de sua ontologia, o capitalismos nos reduz a números, o "outro" será visto apenas como aquele que tem potencial de consumo, ou que se apresenta como um concorrente para a tomada de uma vaga de trabalho, ou ainda, como um marginal da mais alta periculosidade, e o homem passa a ser então, um ser que produz com um custo irrisório e consome de forma insana.

\section{A relação entre produção e liberdade na civilização clássica}

O mundo clássico grego aparentemente não desenvolveu uma teoria específica sobre o conceito de liberdade, pois entendia que esta faz parte das categorias essenciais que constituem o homem, sendo que este é um animal político cujo telos se realiza na vida em sociedade, portanto, o movimento não se dá pela discussão da liberdade, mas quais as fundamentações que o logos nos apresenta, capaz de definir a vida em coletividade como um dos maiores bens que o homem pode ter, tal qual nos expõe Aristóteles na Política. A liberdade no mundo grego não estava no campo do individual, mas inserido no campo da política, com toda a ação característica desta atividade humana, se não inventada pelos gregos, com certeza é nesta civilização que encontramos os fundamentos que ainda regem o mundo ocidental, de forma mais específica nos países que vivem num Estado Democrático de Direito. 
Nas duas obras referenciais para a compreensão da articulação do pensamento grego, a República de Platão (1999) e Política de Aristóteles (1998), a liberdade não é a categoria a ser explorada e muito menos tangenciada, pois na primeira obra a busca é pela construção de uma pólis bela, onde a coesão social será garantida por uma epistemologia da justiça e o Rei-Filósofo será aquele que de posse de um conhecimento ontológico, juntamente com um homem instruído pela paidéia, conduzirá a pólis para que saia da caverna e caminhe em direção ao sol. Os conceitos a serem buscados, tanto de justiça, quanto do que vem a ser o conhecimento, encontram-se no mundo das idéias, mas ambos só podem ser realizados, concretizados dentro das contingências do homem, se cada um destes homens realizarem as tarefas que lhes competem e para a qual foram preparados, ou seja, produzirem o que for necessário para a construção da pólis. 0 artesão deverá produzir o melhor dos artesanatos, o guerreiro deverá dedicar toda sua força e honra para produzir e garantir segurança, o juiz deverá buscar todos os meios necessários para buscar a realização da justiça. Aparentemente as funções de produção parecem-nos separadas, isoladas, como se fosse suficiente que cada um simplesmente fizesse tão e somente, o determinado pela sua função, no entanto, todas as funções idealizadas só encontram o seu telos quando realizadas em função da unidade da pólis. 0 importante é garantir o resultado da unidade que nada mais é do que a busca da coletividade como o bem supremo.

Na sua busca pela cidade ideal, Platão quando da obra A República, seguindo as características próprias de sua dialética (ou resultantes da influência socrática), inicia a sua ascese começando pela definição conceitual do que vem a ser a justiça, passando pela necessidade da paidéia, até culminar com a polis, mas Aristóteles terá uma posição diferente quando da obra Política inicia a construção de suas idéias procurando definir o que vem a ser a pólis, conceituando-a, inicialmente, como o conjunto de uma "comunidade de cidadãos" (Aristóteles, 1998, p. 49), sendo a mesma o resultado das relações entre o casal, depois a família, a aldeia e depois a pólis propriamente dita. A pólis realiza a sua essência quando adquire a autarkheia, em outras palavras, quando passa a ser auto-suficiente no campo político, nas suas relações de poderes, quanto no campo econômico por produzir de forma direta ou indireta, os meios necessários para a sua sobrevivência. Para Aristóteles a pólis existe para proporcionar ao homem uma vida boa, uma vida feliz, e que serão resultados de uma ação coletiva, pois se a felicidade é um ideal individual a mesma se realiza 
tão e somente quando a autarkheia, que é resultado do coletivo, for alcançada. A pólis é formada pelo conjunto de famílias, e as mesmas existem em função de uma relação de propriedade, de uma necessidade de produção e administração dos resultados da transformação do trabalho. Sem a propriedade, inclusive a dos escravos, "só não pode se viver como não se pode viver bem" (Aristóteles, 1998, p. 59), o que estabelece um vínculo forte entre a necessidade de produção e a realização da felicidade contingente e da autarkheia da pólis.

Tanto Platão quanto Aristóteles não tratam a liberdade como um elemento isolado, e nem como um constitutivo imperioso a ser conquistado antes dos demais. Para Platão, primeiro precisamos conceituar o que vem a ser a justiça e depois os demais componentes da pólis. Para Aristóteles é primordial definir a pólis partindo de sua estrutura mais elementar que é o casal, a relação natural entre macho e fêmea, numa nítida relação de produção, e mesmo entre escravos e homens livres. Para ambos a liberdade não é resultado de uma conquista individual, mas parece estar implícita e ser um resultado natural, quando a pólis ideal for conquistada. Ela é resultado do coletivo, não limitada por uma definição conceitual acabada, estanque, com limites para os dois extremos, mas é produto de um movimento constante da própria ação humana e condicionada pela produção material necessária para que o homem possa ser feliz. A liberdade advém com um conjunto de categorias resultantes da autarkheia da pólis, como por exemplo, a felicidade, a virtude a capacidade do homem em se transformar pelo conjunto de ações da paidéia.

Estas relações entre a necessidade de produção e o homem não são primazias nem de Platão e tão pouco de Aristóteles, mas já é construído pela cultura grega, principalmente por Sófocles quando na obra Os Trabalhos e os Dias nos apresenta o trabalho, como resultado de uma ação humana nobre e um esforço benéfico digno, capaz de garantir ao homem prudente sustento nos momentos de dificuldade, além de que, aquele que empreende o seu esforço para produzir, e com isso adquire riqueza é um homem justo. 0 homem ocioso passa fome, e a ociosidade desperta ira nos deuses e nos demais homens (Hesíodo, 1996, v. 300), no entanto, os excessos devem sempre serem evitados, pois a vida do homem é o trabalho e junto deste, traz ele a possibilidade do acúmulo. 0 melhor é que 0 homem possa consumir o resultado do seu esforço, pois se em momentos de dificuldade toma do outro, deve devolver o mais urgente possível e na medida igual ou superior a 
tomada, procedendo assim, este homem que produz é justo e honrado. Os excessos serão sempre punidos pela justiça e o equilíbrio será restabelecido. 0 homem idealizado por Hesíodo nesta obra conquista a sua liberdade, felicidade e honra, quando o resultado de seu trabalho lhe produz o sustento capaz de primeiro saciar a sua fome, e num momento posterior possibilitar o acúmulo necessário aos momentos de dificuldade e se com isso ele adquirir riqueza, e se esta em algum momento perturbar a sua conduta, e com isso lhe conduzir ao ócio, Hesíodo o alerta: "se nas entranhas riqueza desejar teu ânimo, assim faze: trabalho sobre trabalho trabalha" (1996, v.380). É o trabalho que realiza a sua essência garantindo ao homem a sua vida, mas ao mesmo tempo insere-se como elemento social e necessário à construção e continuidade da vida harmoniosa da pólis e da coletividade.

A liberdade no mundo grego não pertencia ao indivíduo, e era expressa somente como resultado das contingências da pólis, pois a esta o homem devia a realização de sua própria essência. 0 mundo romano irá restringir ainda mais essa liberdade, quando em relação a civilização grega, incentiva o acentuamento do direito positivo, limitando ainda mais as ações do homem, com a promessa de retirar a possibilidade de desvios de conduta, uma vez que o Império, e somente ele, pode garantir a vida em sociedade.

Uma das preocupações iniciais e centrais deste direito positivo é o da defesa da propriedade, independente da forma obtida, conforme nos diz Cícero $(1999,1,21)$ ao defender a legalidade da posse da terra, mesmo quando esta fora tomada em tempos antigos pela força da armas, pois este proprietário lançou mão do que the coube em determinado tempo. Procede desta forma para justificar a existência da chamada propriedade privada e propriedade pública, onde na primeira, o resultado de sua produção é de direito exclusivo de quem detém a posse da mesma, e no segundo tipo de propriedade, a produção ou qualquer benefício que dela resultar será destinado não ao povo diretamente, mas somente ao cidadão romano.

Quando no mundo grego existia a predominância do pensamento mítico, o homem ainda tinha esperanças de que o ideal de liberdade fosse obtido junto aos Deuses, pois não havia intermediários nas suas relações. Com a passagem do pensamento mítico, para aquele fundamentado no logos o homem grego sente a necessidade de delegar a um ou vários homens, a tarefa de conduzir e gerenciar as relações entre as diversas fontes de discórdias, próprias da vida em sociedade, é quando começa a esboçar a idéia de Estado, ainda que 


\section{A constituição do estado moderno: do ideal de liberdade para o Princípio da dignidade da pessoa humana}

limitado às contingências da época. Doravante os homens não terão mais as suas liberdades submetidas às vontades e desejos dos Deuses, mas entregaram, de forma paulatina, nas mãos daquele que deveria representar de forma coletiva os seus anseios.

No mundo clássico não havia liberdade individual, inclusive a valentia era um determinante da lei, pois "a valentia perante 0 inimigo até o ponto de dar a vida pela pátria é uma exigência imposta aos cidadãos pela lei, e a sua violação acarreta penas graves" (Jaeger, 2001, p. 138), portanto não havia liberdade entre ser ou não ser um herói, pois a sua não escolha implicaria numa sanção que muitas vezes extrapolava os riscos das batalhas. Se Hesíodo apenas relata as dificuldades pela qual passa o homem inútil, tendo como resultado a fome, o que é desonroso, mais enfático e dogmático é Cícero (1999, III, 30) quando defende que se um homem que é útil à sociedade tomar algo que pertence a um homem inútil, não merece censura da sociedade, reduzindo ainda mais a liberdade e criando um subjetivismo na sua interpretação, em nome da manutenção de uma coletividade. 0 homem que não produz não é útil à sociedade, não importando as causas, deslocando assim a importância do homem enquanto objeto da construção da humanidade, para a produção como sendo o ponto focal para compreender a passagem do sujeito coadjuvante da mesma, que é o homem.

Com o fim do Império Romano e o início da Idade Média, período que irá se estender até por volta de 1400 d.C., época das chamadas grandes navegações, temos mudanças significativas em praticamente todas as relações sociais e produtivas que compõe a história, principalmente pela predominância do cristianismo, fundamentado num dogmatismo que mostrar-se-á implacável diante dos seus opositores. Será um período marcado por uma cumplicidade suspeita entre a classe dominante e a elite religiosa cristã, cuja arma de controle será o pecado e o terror a forma de contenção dos supostos excessos. 0 homem comum, mediano, será relegado ao papel de um pecador inveterado e irrecuperável, pois a sua pobreza é resultado de um pecado, e a forma de expiação será o sofrimento e a submissão aos governantes, que procuram buscar a legitimidade de seu poder, em supostas heranças divinas com algumas tramas bem engendradas, mas muito distantes da sutileza e da beleza das grandes obras míticas gregas.

Não existe mais uma civilização unida pela cultura, pela língua e pela origem mítica, como foi o caso do mundo grego, e nem um império unido pela organização política e 
militar, como fora o Império Romano. A Europa está fragmentada em pequenas extensões de terra, formando os feudos e que por sua vez estavam unidos a um monarca, cujo senhores feudais deviam parte de sua obediência, e de uma forma ou de outra, tanto os primeiros, quanto os segundos, tinham diante de sua autoridade o poder papal que não tinha um exército significativo, mas trazia consigo um poder maior e que assombrava a imaginação do homem desta época: as fogueiras do inferno e as conseqüências pela afronta de um representante de Deus na terra. A obra O Nome da Rosa de autoria de Umberto Eco consegue expressar ao leitor, uma parte desta relação entre terror, temor, liberdade (se é que existia) e o dogmatismo.

A liberdade no mundo terreno será substituída totalmente pela perspectiva de uma vida na eterna Cidade Eterna de Jerusalém, tal qual nos relata Santo Agostinho na obra A Cidade de Deus. Este será o mundo do sofrimento, da expiação, do trabalho que garante a permanência da miserabilidade humana, que reinará doravante na sociedade ocidental. 0 acúmulo como resultado do trabalho será um ideal a ser buscado e alcançado somente pela classe do clero e da nobreza, e estes dividirão os impostos e outras taxas arrecadadas do povo. Pouco ou quase nenhum interesse existe para que o homem alcance uma condição melhor, o trabalho é uma forma de redenção e a miséria um castigo advindo da sua condição de pecador por essência, ainda num referencial originário do mito adâmico, onde Adão e Eva terminam por realizar a escolha errada e a partir deste momento, os homens pagam o ônus desta escolha indevida. Se Platão no Timeu afirmava ser o corpo a prisão da alma, o mundo cristão dirá que "o corpo não é a prisão da alma, mas tornou-se tal por efeito do pecado original, e o primeiro objeto da vida moral é o de nos libertar dele" (Gilson, 2001, p. 153). Liberto do corpo a alma pode buscar na Cidade Eterna de Jerusalém, o seu lugar de aconchego junto ao Pai Celestial, numa contradição da sua própria essência, mas característica das religiões, o cristianismo medieval exclui a possibilidade do outro, pois a salvação chegará somente àqueles que se converterem de forma irrestrita aos dogmas da Igreja Católica, o "outro" não é mais universal mas somente o "outro" que aceita a imposição do dogma.

0 "outro" estabelece-se como oposição, como o lado mal do homem, a sua existência manifesta-se apenas pela sua produção, desde que esta seja útil para manutenção de um estado precário, ainda em formação, mas que já esboça a possibilidade de uma 
positivação das leis, que irá reduzir ainda mais a perspectiva da construção de um mundo ideal, substituindo-o por um mundo ideológico, segundo as perspectivas liberais de Locke, Adam Smith e outros.

\section{Os primórdios do estado moderno: a relação entre os seus objetivos e a base de produção de bens}

Com o fim da Idade M édia, marcada segundo historiadores com o início das grandes navegações em 1400 d.C., e a contribuição das ciências, principalmente com a teoria de Copérnico (1473-1543) segundo a qual a "terra tem um movimento diário em torno de seu próprio eixo e um movimento anual em torno do sol estacionário" (Magee, 1999, p. 64), deslocando a terra como o centro do universo e colocando em choque as teorias de Ptolomeu, e a cosmologia aristotélica explorada principalmente por Tomas de Aquino. A autoridade dogmática da Bíblia e da Igreja Católica é colocada em risco e a dúvida começa a pairar, sobre um conhecimento que se julgava verdadeiro e acabado. É um conflito entre o antigo e novo que se começa a formar, entre a tradição e a ciência que agora busca a sua autonomia e inicia o processo de relativização do conhecimento.

Com o início da modernidade temos o caminhar final do feudalismo, onde o sistema de produção estava centrado no trabalho braçal, e na sobrevivência precária do vassalo. Ao senhor feudal pertencia o resultado do trabalho do homem, e acima daqueles, tínhamos os reis e soberanos que governavam extensões maiores de terras, e no ápice deste sistema estamental temos o clero. Não havia possibilidade de ascensão entre vassalo e senhor feudal, ou para as duas outras classes, mas a nobreza era a que fornecia o elemento humano necessário à classe sacerdotal, onde a principal exigência situava-se na posse de extensas propriedades e influência de poder. Embora a relação entre senhor feudal e vassalo não fosse de uma escravidão oficializada, pois o primeiro era supostamente livre para deixar o feudo e ir viver em outro local, como podemos dizer que é livre o homem que tem diante de si apenas duas escolhas: viver sob a forma de servidão e morrer trabalhando para um senhor que nem ao menos the reconhecia o mínimo da condição humana, ou sair e morrer de fome pois este não possuía outra possibilidade de trabalho, a não ser aquelas práticas resultantes da agricultura? Sem propriedade não é possível produzir e portanto, viver com o fruto do seu trabalho, e a Europa do final do século XV já está praticamente toda dividida entre 0 
clero e a classe nobre e muito pouco restou para uma legião de homens, que não tiveram a possibilidade de obtenção de terras e propriedades.

Se no período em que prevaleceu o pensamento mitológico, o homem ainda imaginava que a intervenção dos Deuses no mundo terreno poderia alterar a sua situação, seja ela moral, material e espiritual, a medievalidade rotulou este homem como pecador inveterado, lançou a possibilidade da realização das suas aspirações para a outra vida, 0 surgimento do Estado Moderno limitou ainda mais as suas possibilidades, pois positivou as leis não para garantir o direito de todos, mas sim o da burguesia ascendente e da nobreza, garantindo primeiro o direito à propriedade e depois o direito de quem possui a propriedade fazer o que for necessário para a sua manutenção e expansão. Este direito não foi aquele escolhido pelo homem mediano, como resultado de uma reflexão e vontade da coletividade, mas sim aquele que garantiu as conquistas da classe dominante, e apenas sentiu a necessidade de formalizar alguns direitos, com o intuito de cobrar de forma efetiva os deveres da maioria do povo.

0 mundo grego criou a política como a forma de resolver os conflitos causados pelos particulares, mas que afetam a harmonia da pólis, e "se a atividade política é nobre por excelência, a razão está no fato de que nenhum cidadão poderia romper seu compromisso com a continuidade da Cidade à qual é destinado, da qual recebe sua educação" (Ruby, 1998, p. 13), sendo o poder político derivativo da responsabilidade de dirigir a pólis à sua autarkheia. Para Locke (2001, II, 3), considerado por Magee (1999) "0 Supremo Liberal", e um dos filósofos a defender o Estado Moderno, o poder político tem por finalidade editar as leis para garantir o direito à propriedade, utilizando para isso, toda a força necessária. É uma visão que expressa muito bem o seu caráter liberal, assim como uma defesa incontingente do direito de propriedade, atendo-se muito mais a questão da legalidade da possa da terra, do que da legitimidade da mesma. Um outro aspecto a ser considerado é que a garantia da posse, externa na sua posição antagônica a restrição da liberdade de outrem, uma vez que a política, outrora representante dos direito coletivos, neste momento passa a assumir a posição de defensora quase que exclusiva, daqueles que possuem a propriedade. É a admissão de que a desigualdade gerada pela posse é muito mais um problema de ordem natural, do que resultante do desequilíbrio entre as relações de 


\section{A constituição do estado moderno: do ideal de liberdade para o Princípio da dignidade da pessoa humana}

produção, e neste caso, o poder político não só reconhece este fato, como garante a sua continuidade, acentuando as diferenças e não interferindo na estrutura que o constitui.

A liberdade não é mais um ideal a ser buscado, conquistado, mas sim um dos elementos que só pode ser alçado através da lei, pois "onde não lei, não há liberdade. A liberdade consiste em estar livre de restrições e de violência por parte de outros" (Locke, II, 57), o direito positivo é que irá determinar 0 grau de liberdade e não mais o ethos, 0 movimento interior capaz de transformar o homem num ser que educa e é educado pelos bons hábitos, pois somente a vida harmoniosa com o todo pode garantir a perspectiva de uma liberdade libertadora, e não de uma liberdade supostamente garantida e restringida pela lei, onde o princípio é a defesa da propriedade e não as causas que impõe ao homem a condição de um vassalo.

Da necessidade da criação de um poder político como forma de garantir o direito a propriedade, podemos inferir que a preocupação principal do Estado Moderno encontra-se na base de produção e que os homens são apenas o meio para obtenção do acúmulo de riquezas. 0 Estado não surge com o objetivo de fazer uma reflexão sobre uma história onde o homem é o seu ponto central, o seu grande foco, e a origem de sua criação, mas principalmente com a intenção de agir como elemento material, que se expressa através do princípio de coercitividade, que é uma das características da lei, e se manifesta com uma legitimidade questionável, com a utilização da força bruta, não como restaurador de um possível direito que garanta ao homem uma vida feliz e que possa viver bem, com o resultado de seu próprio trabalho, mas antes, como um instrumento da classe dominante para dar continuidade a uma história que parece se manifestar de forma determinística: manda quem pode, obedece quem não tem forças para reagir e quem pode, já conseguiu a sua condição em tempos históricos remotos, aos demais destina-se apenas o cumprimento da lei. Neste sentido temos uma função reducionista do Estado e muito próxima da teoria kelsiana, onde o "Estado é uma organização política por ser uma ordem que regula o uso da força, porque ela monopoliza o uso da força" (Kelsen, 2005, p. 273), sendo assim o Estado nada mais é do que um promotor do uso da força e um órgão ao qual o cidadão deve antes temer, do que depositar nele a possibilidade de resolver os conflitos causadores das diferenças de condições materiais e morais, com a finalidade de formar um cidadão capaz de ser e agir politicamente. 0 Estado protege a propriedade pelo uso da força, garante as 
condições de produção e aos demais resta apenas à função de consumir, pois produçãoconsumo será o ponto de equilíbrio que irá garantir a continuidade da classe dominante.

O Estado Moderno abandona a perspectiva de agir como formador do cidadão, tal qual nos reporta Platão na obra A República, ou ainda Aristóteles na Política, para assumir um papel predominantemente de agente repressor, principalmente contra aqueles que não concordam com as suas leis e encontram barreiras praticamente intransponíveis na estrutura interna do Estado, para mudar as leis, e estas passarem assim, a representar o interesse do homem mediano, e não somente de uma classe minoritária, mas influente e

determinante nas decisões do Estado. Posição semelhante tem aquela defendida por Hobbes (1979) onde uma vez eleito o soberano, ao povo cabe apenas obedecer as suas leis, pois este é o melhor de todos os homens, o mais puro em suas intenções e livre de qualquer influência que caminhe contra os interesses daqueles que o elegeram. É uma liberdade cuja prática se restringe a uma única vez: quando o cidadão elege o seu soberano e a partir deste momento resta-Ihe apenas obedecer a lei, "pois é evidente que a lei, em geral, não é um conselho, mas uma ordem" (Hobbes, 1979, p. 161). 0 Estado hobbesiano tem na sua origem a segurança dos bens materiais, além de constituir-se de um elemento quantitativo, em outras palavras, no estado de natureza uma família, ou uma pequena aldeia não teria condições de defender-se contra aqueles que poderiam se apropriar de seus bens, tendo então que se associar a um número maior de homens com a finalidade de formar um Estado, cujo número de armas fosse o suficiente para causar temor àqueles que supostamente se aventurassem em aumentar as suas posses. Para preservar e ampliar a propriedade o homem abre mão de parte de sua liberdade, e no caso hobbesiano, de forma quase que irrestrita, uma vez que o soberano detém como seu legítimo poder, o destino da vida dos homens, podendo inclusive condená-lo à pena de morte.

Posição diferente de Hobbes assume Rousseau para o qual o homem abre mão de uma liberdade plena do estado de natureza, mas que Ihe impunham riscos que poderiam estar além de suas forças, para conquistar outras liberdades, inclusive àquela que iria garantir a manutenção de suas posses e de sua própria vida. Contrariando o pensador inglês, Rousseau (1999, Vol I, p. 53) defenderá a posição de que o homem age de forma sábia quando reage ante o soberano que the usurpar de uma liberdade que não fora explicitamente concedida no contrato social, e de forma mais enfática e clara nos diz que a 


\section{A constituição do estado moderno: do ideal de liberdade para o Princípio da dignidade da pessoa humana}

origem da sociedade e das leis é porque "sendo a força insuficiente para conservar o que adquiriu, o rico, a fim de legitimar sua posse, imagina dar aos homens máximas e instituições além das naturais" (1999, Vol. II, p. 23) o que retoma a nossa questão inicial, de que o Estado Moderno trata a liberdade em relação direta e quase que irrestrita com os meios materiais necessários a produção, e não invoca a necessidade de um resgate ontológico do homem, e sim o reduz à condição de materialidade.

\section{O estado moderno e a constituição: a materialização do homem}

A Revolução Francesa em 1789, cujo marco foi a queda da bastilha, muito mais um símbolo do ancien regime do que uma prisão propriamente dita na época, pois dentro da bastilha além de armas fora encontrado apenas "sete prisioneiros: quatro falsários, dois loucos e um jovem aristocrata" (Magee, 1999, p. 123), serviu como um modelo ideal de revolução para outras regiões da Europa e do mundo, porque marca supostamente, a diluição dos poderes da nobreza e do clero com o surgimento do chamado Terceiro Estado, e a exigência do voto igualitário como aquele capaz de garantir os desejos e anseios da maioria, até este momento da história desprezada, se é que existe um momento posterior a este, em que os desejos do Terceiro Estado foram realmente atendidos. Até este momento temos uma convivência pać́fica entre o liberalismo e o autoritarismo; o primeiro criara as fundamentações filosóficas e políticas para a defesa da propriedade e da existência de um soberano para dirigir as forças dos homens comuns, o segundo usava de uma suposta legalidade e também legitimidade infundada, para justificar o uso da força bruta como forma de conformar o povo na sua condição de inferioridade ante o clero e a nobreza.

Não podemos nos esquecer que a Revolução Francesa foi uma revolução arquitetada pela burguesia, mas realizada na prática, no campo de batalha, pelo povo, que contribui com a sua força e ingenuidade, mas muito pouco usufruiu destes resultados. A burguesia busca ampliar os seus direitos e a garantia de sua propriedade, e entra em choque com uma nobreza decadente e endividada e que se recusa a sair de sua categoria, o clero enfraquecido mediante a decadência da nobreza e ainda tendo que enfrentar os resultados da Reforma Protestante, também não quer abrir mão de qualquer suposto direito, até porque as teorias jusnaturalistas procuram fundamentar a todo custo os seus direitos, pois é justo "dar a César o que é de César", e César agora é representado pelo Clero. 
Antecedendo a Revolução Francesa e sofrendo o ofuscamento produzido pela mesma, Sieyès (2001) publica em janeiro de 1789 a obra A Constituinte Burguesa, onde fundamenta a existência e importância do chamado Terceiro Estado, nominando-o de "um homem forte e robusto que está com um braço preso" (2001, p. 3) e que a nação é constituída de homens de todas as classes que vivem sob a mesma lei e esta não pode dar privilégios a alguns, de forma a manter e acentuar as diferenças. Reconhece que a constituição, quando elaborada pelos dois primeiros estados, ou seja, o clero e a nobreza, acentua as diferenças, produz conflitos e gera insatisfação, portanto, se é inevitável a elaboração de uma constituição, ao menos que essa seja feita pelo povo, pelo Terceiro Estado.

Um conceito quase que unânime de Constituição nos países democráticos, é que esta deve representar uma vontade geral, seja resultado de uma Assembléia constituída especificamente para este fim, ter em seu corpo constituinte representantes dos mais diversos segmentos da sociedade, no entanto, o resultado da constituição não deve ser a expressão de uma vontade particular, "mas a vontade soberana da nação, isto é, a unidade política" (Duso, 2005, 212). Parece-nos que o movimento reflexivo se dá sempre no sentido de compreender os mecanismos e os aspectos meramente jurídicos e necessários, para a elaboração da constituição e não a busca da articulação das intenções quando da elaboração e execução das mesmas, reduzindo-a a um mero instrumento burocrático-jurídico capaz de permitir a existência de um ordenamento jurídico, onde a sua principal preocupação é a garantia da propriedade, que na realidade já se faz de longa data, e incluir sob a forma de promessas que serão cumpridas somente mediante situações especiais, direitos que em outras épocas pertenciam ao homem, não fundamentado num suposto jusnaturalismo, mas antes conquistas resultantes de uma análise reflexiva e totalizante da história, da compreensão da economia e das intenções da classe dirigente e dominante, da convivência intrínseca da cultura e da história que o próprio homem constrói, enquanto um sujeito que sofre e faz história. 0 homem não é o seu objeto principal de guarida, porque antes dele aparece a propriedade e a necessidade imperiosa de sua proteção, então temos um deslocamento de valores pois não nos importa mais conhecer o homem em sua ontologia sendo suficiente reduzi-lo à materialidade, e atribuir uma valor financeiro e um número nos dados estatísticos, como por exemplo, se dá na população carcerária de nosso país onde o 


\section{A constituição do estado moderno: do ideal de liberdade para o Princípio da dignidade da pessoa humana}

destaque que se dá é na quantificação da existência da raça negra, ou mulato como queiram, mas não se procura apresentar quais as razões históricas e econômicas para estes números. Não esclarece que num determinado momento da história a Princesa Isabel libertou os escravos e prendeu os negros, pois Ihes deu a liberdade e eles foram expulsos da única atividade econômica que realizavam com eficiência, sem as menores condições materiais para ali continuarem, e nem a possibilidade de adquirirem conhecimentos que poderiam levá-los a outras atividades, jogaram eles na rua, a deriva num mar sem referência, ao mesmo tempo em que a lei defendia o dever do Estado em realizar prisões por "vadiagem", então o escravo liberto termina por ser preso novamente, mas agora por um outro motivo, pois se o primeiro motivo ofendia o direito à liberdade e uma ofensa à própria condição de humanidade, o segundo apenas cumpre um dispositivo legal.

Uma das características do Estado Moderno é o de possuir um ordenamento jurídico, onde a Constituição seja a lei maior e de onde deverá derivar as demais normas. As constituições modernas, segundo Canotilho (2003), tem por objetivo garantir a liberdade dos cidadãos, o acesso aos direitos, mais individuais do que coletivos, e finalmente, limitar o poder político, através do sistema de contrapeso entre os poderes. Historicamente as constituições realizaram de forma exemplar os desejos da classe dominante, disponibilizaram uma série de direitos cuja existência fica sempre no campo das promessas, mas procura de forma clara e objetiva limitar a atuação do Estado no campo econômico e social, definir o direito de propriedade, como aquele capaz de garantir a estabilidade das relações sociais e ser um grande incentivador para que o homem trabalhe, pois o trabalho dignifica o homem, não importando o quanto ele receba por este esforço. Enquanto instrumento de defesa da propriedade as Constituições tem realizado o seu papel com eficiência e respostas imediatas, principalmente quando em nome de uma suposta "segurança jurídica", o Estado fornece plenas garantias ao capital externo, pouco importando qual será o modelo de exploração a ser utilizado, e tão pouco o quanto isso pode contribuir para o desenvolvimento e as melhorias de condições de vida do povo. Devemos deixar claro que a crítica aqui apresentada não se faz pela destituição plena desta posse, mas sim quanto aos benefícios sociais que ela pode realmente trazer, ou seja, se a propriedade realmente cumpre a sua função social, tal qual determina a Constituição. 
Uma forma direta de apresentar a Constituição como resultante da vontade geral, é 0 de primeiro garantir o direito à liberdade, para num momento próximo limitar o mesmo, acentuando o direito à propriedade, pois a liberdade termina por ficar sempre no campo da subjetividade e sua realização dependente de uma série de conjunção de fatores, quase sempre impossíveis de serem realizados, ao passo que a propriedade situa-se no campo da objetividade e diante de conflitos, os mesmos se resolvem de uma forma simples e direta: quem possui o título de propriedade? É um problema simples e pode ser resolvido de forma concreta, material, na grande maioria das vezes de forma imediata. A liberdade ao direito de posse da propriedade está garantida. Um dos fundamentos do postulado liberal de John Locke foi totalmente cumprido. A liberdade se materializa pela propriedade e o homem que tem propriedade realmente existe. É um ser concreto e com liberdade de dispor da sua propriedade como melhor the prouver.

Mas o que dizer do homem que não tem propriedade? 0 que fazer com ele? Para M arx (1999) este homem ainda não está destituído de todas as suas propriedades, pois ele ainda tem a propriedade sobre a sua força de trabalho. Ele ainda pode dispor desta força e receber algo em troca, pois a própria Constituição é contra a escravidão e ainda garante 0 direito ao trabalho. Este homem ainda tem a liberdade de vender a sua força de trabalho. 0 problema então situa-se num outro campo: qual a extensão desta liberdade? Ou ainda: quais as condições para a realização desta liberdade? 0 capitalismo e as teorias que sustentam a sua estrutura de apoio resolvem este problema com o princípio da autonomia da vontade, já fundamentada nas teorias de Rousseau (1999), onde os homens aderem ao contrato social por sua livre e espontânea vontade, pois o homem é livre para fazer aquilo que melhor the prouver, contudo, como admitir que diante da supremacia do capital, do excesso de mão-de-obra produtora, e da escassez de empregabilidade, pode o homem ser livre para decidir se assina ou não este contrato? Ora, só pode haver igualdade na assinatura deste suposto contrato, quando as condições entre as partes são efetivas e reais e não apenas formais. Esta é mais uma das promessas do Estado Moderno e que não será cumprida, mas acentuada com 0 avanço da flexibilização das relações de trabalho e com a virtualização do capital. 


\section{A liberdade como um ideal e a liberdade do estado moderno}

Argumentar sobre a liberdade ideal nos remete de forma inevitável, procurar compreender o mundo antigo e de forma mais específica a história antiga clássica, tendo como referencial o mundo grego. Uma liberdade existente num mundo ideal, harmônico, num universo organizado, e então, o demiurgo (Platão, 1999) contemplando um modelo perfeito de liberdade, entrega aos homens uma cópia, ainda que pálida, sujeita as limitações existentes no mundo contingente, que ainda não é a verdadeira, mas que no movimento do devir, do engendramento das mudanças, pode vir a ser. Saindo do campo das questões metafísicas e adentrando ao campo da dialética platônica (seja ela uma criação de Sócrates ou de Platão), podemos inferir que o "modelo originário, enquanto puro ser, é objeto de ciência, que alcança verdades incontrovertíveis" (Reale, 1994, Vol II, p. 133), em outras palavras, um modelo inatingível, mas que deve ser buscado, pois o belo e o perfeito só podem ser compreendidos quando conhecermos a ontologia do ser. Quanto à "imagem desse modelo (e, portanto, o nosso cosmo físico que é justamente imagem) é objeto de opinião" (Reale, 1994, Vol II, p. 133), e sendo opinião (doxa) pode até ter uma fundamentação do logos, mas não é um conhecimento verdadeiro, uma episteme, pois as opiniões dos homens situam-se no campo das sensações e podem ser alteradas pela retórica do discurso, como Sócrates acusa os sofistas de construírem verdades contingentes às suas necessidades momentâneas, mas que não encontram sustentação epistemológica.

Mas o que vem a ser o "ideal"? Para Kant o "ideal é um ser concebido como único, individual e tal que satisfaça exatamente todas as condições de uma idéia [...] que a razão reclama, mas de que a experiência não fornece exemplo" (Lalande, 1996, p. 485), é algo que é perfeito e nenhuma experiência do mundo sensível pode acrescentar algo ao seu ser. Ele existe por si e compõe o universo harmônico e organizado, "ainda que impossível de realizar, um tal ideal serve de regra e de protótipo para agir e julgar" (Lalande, idem), são referenciais construídos pela humanidade no seu caminhar, cuja perpetuação se dá pelo resultado de lutas e conquistas do homem para se libertar do julgo daquele que governa, ou tenta governar pelo uso da força bruta, suprimindo o "outro" e impondo o monólogo da força estúpida e irracional.

A liberdade idealizada pelo mundo grego não se estabelece "em relação a", mas sim na possibilidade do homem grego enfrentar e conter a hýbris, ou seja, o excesso, a 
desmedida, o impetuoso, o violento, e com o uso do logos encontrar o que Aristóteles na Ética a Nicômaco chama de "meio-termo" que é a justa medida das coisas. A realização desta liberdade só existiria quando o homem estivesse inserido na pólis, não como um escravo, mas como um homem livre e que necessariamente participasse da vida política da pólis, entretanto isso ainda não era suficiente, pois um cidadão grego devia obediência às leis, concedendo inclusive, o direito a sua própria vida, pois a recusa em defender com a própria vida a autarkheia da pólis, geralmente era punida com a morte ou o exílio. 0 grego era livre para ser grego. E ser grego exigia obediência às leis. Sócrates, o "mais ateniense dos atenienses" (Wolff, 1987) foi um homem livre até a sua morte, pois abriu mão de sua própria vida, uma vez que a possibilidade de exílio fora aventada em seu julgamento, e a fuga poderia se realizar com certa facilidade, mas ao encarnar em si o modelo de um ateniense ideal, torna-se livre para entregar a sua vida a serviço da pólis. Mostra para Atenas que os seus valores estavam sendo corrompidos, e que o ideal universal estava sendo substituído pelos desejos pessoais de seus governantes. Sócrates não desejava a liberdade "relativa", pois ao ser exilado ou fugir, a sua liberdade seria relativa a uma cidade qualquer, desde que excluísse Atenas. Ele desejava a busca de uma liberdade ideal e construída pela realização na pólis, uma liberdade garantida por princípios fundamentais que se sustentassem pela sua essência, refletindo assim a sua universalidade. Não era suficiente ser livre apenas em Atenas é necessário ser livre em qualquer cidade da Grécia. Sócrates morre como um homem livre, embora tenha recusado fugir de Atenas. É livre porque se recusa a ter a liberdade de desobedecer à própria lei e ao obedecer às leis da pólis se liberta de ser acusado de corromper os jovens, para Chauí (Apud M erleau-Ponty, 2002, p. 206), “Sócrates tem um jeito de obedecer que é um jeito de resistir".

Mesmo na medievalidade com toda a força repressiva e moral da cristandade, fundamentada numa verdade revelada, a Bíblia, nos entrelaçamentos econômicos e políticos que a Igreja travava em seu interior, os conflitos com a religião Islâmica e a sua ascendente importância e contribuição na filosofia, assim mesmo tínhamos um ideal de liberdade, centrada na doutrina da redenção do homem, pois se o corpo físico, material, que nos impõe limitações, dores, desconforto, prazeres lascivos, entre outros é resultado de um pecado original (Gilson, 2001), a liberdade por ser conquistada pela conduta moral sustentada pela Igreja, principalmente na figura do Papa, seu representante espiritual e político, e assim o 
homem se liberta das contingências deste mundo e sua alma conquistará o paraíso. A busca desta liberdade irá determinar as ações dos homens, influenciando de forma direta todas as relações sociais, entre as quais a economia. A fé também gera uma necessidade de produção e consumo na medievalidade, em nome da liberdade a ser conquistada pela alma, quando na Europa inicia-se a construção das grandes catedrais, como em Bolonha, Chartres, Córdoba, Florença, entre outras, e com estas temos o surgimento de um mercado interessante, a venda de supostos ossos, coração, cabeças e outros órgãos, para financiar a construção destas catedrais (Marchi, 1992). Em nome da fé e da liberdade, estabelece-se uma rica relação de produção-consumo e expõe a contradição resultante da materialização do sagrado, quando se acentua as diferenças de classes, e a própria religião concorda em buscar fundamentações para justificar os direitos divinos dos reis e impor à classe humilde da população a sua permanência na miserabilidade, como forma de resgate do pecado original. 0 custo da liberdade será determinado por uma moral rígida e determinista, um código canônico inflexível, principalmente para aqueles que, mesmo de forma justa, reclamavam dos excessos da classe dominante, mas ainda resta um ideal de liberdade a ser conquistada, e ele poder ser realizado pela redenção do homem.

O Estado Moderno traz para a liberdade uma nova perspectiva, quando a insere como conseqüência das relações de produção e consumo, dando à propriedade a primazia de centralizar as relações de direito. A positivação do direito à propriedade no Estado Moderno, tem como um dos referenciais principais Locke ao defender a posição inicial de que Deus concedeu a Terra para os homens trabalharem e produzirem o necessário ao seu sustento, e "a condição da vida humana, que requer trabalho e materiais com o que trabalhar, introduz necessariamente a propriedade particular" (2001, II, 35), sendo assim, a propriedade da terra não deve atender ao bem coletivo, mas num primeiro momento reduzir-se ao particular, para em seguida, quando da produção além do necessário à sua sobrevivência, possa ser negociado, permitindo assim o acúmulo de bens com a criação do dinheiro e a possibilidade de expansão da propriedade da terra. Doravante a condição para aquisição da propriedade estará condicionada pela existência de capital, e somente terá condições de produzir mais, e assim acumular mais, quem tem capital.

Mas o que fazer com o homem que não tem propriedade, e portanto está destituído da condição primária de produzir para acumular? Para Locke $(2001,11,27)$ esse 
problema pode ser resolvido se considerarmos que cada homem tem como primeira e inalienável propriedade a pessoa humana, portanto, o trabalho e qualquer ação resultante deste corpo são de sua propriedade, e se este homem não tem terras para produzir ele deverá vender o seu próprio trabalho, para garantir o seu sustento e poder acumular bens. Sem dúvidas de que no contexto atual esta teoria pode nos parecer ingênua, até porque 0 valor do trabalho não é regulado por quem detém a propriedade do mesmo, no caso o trabalhador, mas sim pela lei da oferta e da procura, atividades reguladas pelos detentores do capital. A questão da liberdade insere no direito à própria propriedade, que de forma física já cria um limitador ao estabelecer limites entre as terras, com a confrontação de suas divisas, na questão da humanidade, retira dos homens a possibilidade de reter o espaço suficiente para produzir com a finalidade primeira de garantir o seu sustento, e depois de que o excedente seja destinado à solução dos conflitos resultantes de uma desigualdade de condições materiais, procurando assim o equilíbrio de classes para num futuro, ainda que utópico, venhamos a ter a supressão de classes, dentro de uma construção ideal de mundo, para recuperarmos parte dos postulados de Marx.

A Revolução Francesa trouxe consigo a estruturação do Estado Moderno, tal qual existente nos dias atuais, principalmente no âmbito jurídico, onde temos o estabelecimento da Constituição ou Carta Magna, como o instrumento jurídico resultante de uma suposta vontade da maioria, e um fanal capaz de orientar as demais normas, assim como a responsável por dar as garantias iniciais à propriedade e todas as garantias econômicas conseqüentes a esta, e supostamente resguardar os direitos do cidadão que agora passam a se chamar "direitos que protegem a dignidade da pessoa humana" e de forma enfática, deixar clara a supremacia do Estado no uso da força bruta, assim como da arrecadação fiscal. As garantias efetivas ocorrem sempre no campo econômico e da propriedade, as demais nos parecem apenas como uma utopia que o Estado não se apresenta muito propenso a realizar, a não ser, nos casos em que a ordem política do momento, possa tirar proveitos eleitorais de programas assistencialistas que além de não resolver o problema, cria uma indústria política de troca de favores.

Antes da Revolução Francesa havia pelo menos a perspectiva de uma possível ruptura, para a implantação de um Estado que caminhasse em busca de uma condição humana ideal. 0 problema é que a Constituição é um elemento muito mais organizador das 


\section{A constituição do estado moderno: do ideal de liberdade para o Princípio da dignidade da pessoa humana}

forças que compõe este Estado, do que um instrumento garantidor do estabelecimento de um equilíbrio entre as forças de produção e de consumo. Um dos exemplos é que a maioria das Constituições, inclusive a brasileira, refere-se à garantia de um salário mínimo, e não de um salário ideal, mas quem estabelece este mínimo? É notório que o mercado regula este salário uma vez que o capitalismo, tal qual previra Marx, criou um cinturão de reserva de mão-de-obra situando-se numa periferia miserável e pronta a assumir a sua posição a qualquer momento, mesmo que a proposta da compra de sua força de trabalho, leve consigo a sua alma. Sendo assim, regulou-se a força de produção, estancou a sua possibilidade de reação, da realização de um ideal, em troca de garantias que expressam as necessidades de sobrevivência do mercado e não do homem.

No positivismo dogmático jurídico, leis posta é lei a ser obedecida sem contestação, porque ela foi constituída pelos representantes legislativos do povo, independente dos artifícios imorais e mesmo ilegais de tal eleição, e expressam a vontade do povo, portanto, 0 mínimo que resta ao cidadão é o seu cumprimento, e o máximo é não enfrentar as questões de legitimidade de interesses coletivos da lei. 0 objetivo das revoluções sempre foi 0 de produzir uma ruptura, assim o eram a maioria das promessas, principalmente com a Revolução Francesa, a Revolução Russa, para citarmos apenas as mais conhecidas historicamente, no entanto, embora as mesmas tenham sido realizadas com a força das massas, do homem comum, do homem angustiado, desapontado e desacreditado com os regimes vigentes, as rupturas não ocorreram e o que observamos foi apenas uma transformação, onde parte do velho permaneceu e o novo procurou se adaptar à ordem já vigente. Na realidade não ocorreram alterações significativas, mas apenas a troca das classes dominantes e a manutenção do ímpeto liberal e capitalista, concedendo sob formas de compensação, cuja subjetividade encontrava modos de conter a sua realização, às classes menos favorecidas e que agora estavam destituídas da possibilidade de realização de qualquer ideal. A própria organização política e jurídica do Estado, tratou de colocar à margem da lei toda e qualquer perspectiva de uma revolução, negando justamente um dos pilares que levaram à sua construção. 0 capitalismo é um sistema que vive e sobrevive de suas próprias contradições. Promete num primeiro momento, com a finalidade de conter os espíritos animosos e depois de passada a fase crítica, procura encontrar uma racionalidade para justificar a impossibilidade das realizações destas promessas. E mais grave ainda é que 
- Estado acaba encontrando esta racionalidade, quando encontra na precariedade da arrecadação fiscal contingente e geradora de caixa para o Estado, a razão contábil para 0 não cumprimento destas promessas. E quando falamos em arrecadação, quem mais paga imposto em nosso país, e também nos demais? É a classe trabalhadora que tem os seus tributos descontados diretamente em folha de pagamento.

Quanto ao sistema de produção na realidade as Constituições o cercaram de todas as garantias, uma vez que positivou de forma clara e indubitável o direito à propriedade, e mais recentemente deram garantias para a virtualização dos capitais, temos agora 0 "ciberespaço como metáfora do dinheiro" (Alves, 2000, p. 51) junto com o capital não vem o esforço humano da transformação, pois as grandes empresas não mais precisam do setor de transformação. O capital agora circula pela internet de forma "líquida", onde os riscos são sempre minimizados por garantias governamentais e jurídicos, mas os ganhos ficam restritos às grandes corporações. Qual será então a relação de produção? Nenhuma, senão aquela que por si só produz mais capital.

Qual seria a esfera da liberdade e o conceito de homem, no âmbito desta Constituição que foi parida e usou a energia do sangue de milhares de homens que foram de forma ilusória, conduzidos ao seu próprio matadouro? A liberdade fica restrita apenas naquilo que a Constituição e as normas jurídicas não estabelecem os limites, e ainda, nas limitações impostas pelas condições materiais, que são controladas pelo mercado, sendo assim, um pai de família que por motivos diversos não tenha tido as condições para uma formação profissional condizente com as exigências do mercado, tem a sua liberdade limitada ao seguinte: morrer passando fome, mas morrer com dignidade. Pois não é o sistema que se apresenta de forma injusta, mas é ele que não foi capaz de compreender o submundo das intenções econômicas e assim padece pela sua ignorância e ingenuidade. As coisas parecem que se resolvem de forma simples na ótica capitalista; ainda existe a liberdade de morrer!

Em tempos de outrora, o homem ainda tinha o ideal de buscar a construção e formação de um homem tal qual os heróis gregos e romanos, alguém que devido as suas qualidades não seria um mortal comum, e devido à algumas limitações também não seria um Deus, ao menos tinha a perspectiva de ser um Semideus, era um ideal utópico é verdade, mas era uma motivação para se viver, um motor capaz de mover as ações humanas dentro 
de uma perspectiva ética, tal qual aquela idealizada por Aristóteles, na obra Ética a Nicômaco.

A condição ontológica do homem foi reduzida à existência do respeito à "dignidade da pessoa humana", e assim o importante não é mais garantir o suficiente, mas sim dar garantias precárias, subjetivas, para supostamente garantir o mínimo, mesmo sabendo que o Estado nem a isto irá garantir. No lugar do salário ideal e necessário para que o homem viva como homem, coloca-se o salário mínimo que será o suficiente para que ele viva e rasteje pelos programas sociais, muito mais eleitoreiros, do que solucionador das causas, dentro de condições que não ferem a sua dignidade, pois isso Ihe foi tirada há muito tempo, mas sim a ferir a sua condição de homem, buscando-a na sua essência. A garantia da dignidade da pessoa humana é uma redução vil da condição do homem, até porque, no capitalismo parece-nos que este enxerga a possibilidade de que um trabalhador vendendo a sua força de trabalho, com uma jornada de 44 horas semanais, possa sustentar uma família, recebendo um salário mínimo, e pior ainda, o Estado the concede, com uma bondade angelical, um salário mínimo de aposentadoria, para ele desfrute os míseros restantes dias de suas vidas, vivendo como um aposentado que rasteja pelos postos de saúdes e hospitais. No campo da saúde pública as contradições são maiores ainda, ou será que é parte positiva e construtiva da dignidade humana, as pessoas doentes se empilharem como entulhos em corredores de hospitais e postos de saúde? Na segurança pública as coisas se mostram mais caóticas ainda, ou será que é digna uma criança morrer com uma bala perdida, resultante da ineficiência do Estado em controlar a criminalidade, quando volta da Escola para casa? Neste setor até o "crime é organizado", mas o Estado ainda não encontrou a fórmula "motivacional" para que os seus comandados enfrentem a criminalidade, não de forma igual, pois isso seria um absurdo, mas de forma superior.

Mas onde então encontraríamos uma possível solução para a superação desta liberdade capitalista? 0 Estado capitalista só compreende a coletividade como resultado da soma da produção de cada um, por exemplo, quando analisa a renda per capita e depois na soma da potencialidade de consumo individual. A coletividade garante somente 0 lucro produzido pelo lixo gerado pelo próprio sistema. A questão da conquista da liberdade, se inevitavelmente a ligamos ao trabalho, é procurar tal qual nos expressa Hesíodo na obra Os Trabalhos e os Dias, a perspectiva de um trabalho com finalidade social que seria ocupado 
inicialmente por esta massa de trabalhadores excluídos e situados na marginalidade do cinturão de reserva de trabalhadores, conforme já previsto por Marx.

\section{Conclusão}

O Estado Moderno construiu seus alicerces tendo como estacas vivas, a miserabilidade de uma classe impotente de reação. Empenha defesa máxima e concreta na proteção da propriedade, a estas as leis são claras, explícitas, não deixam lacunas e são totalmente objetivas. São ações realmente garantidoras e incentivadoras de sua manutenção, pois garantir a propriedade, tal qual expressa John Locke, ainda é a forma mais tranqüila de fazer imperar o direito. 0 foco não é o homem, mas a propriedade e o consumo.

Quanto às garantias que efetivamente poderiam dar ao homem mediano, comum, de melhorar as suas condições materiais para alçar um equilíbrio maior de sua totalidade, estas situam-se apenas no campo das promessas e de leis cujas subjetividades ficam para serem interpretadas pela classe dominante, pois o cumprimento de algumas destas promessas poderiam colocar o sistema financeiro, as economias globais e outros, em risco eminente o que poderia supostamente desequilibrar e colocar em risco os projetos da elite dominante, cuja urgência normalmente se estabelece a curto prazo, enquanto aquelas que visam restituir a condição ontológica do homem, só podem ser realizadas a longo prazo, aliás, a prazos muito longos! Tão longos que a humanidade pode até não sobreviver para ver sua realização.

\section{Referências}

ALVES, Giovani. Internet: arcabouço midiático na era da financeirização. http://antiga.bibvirt.futuro.usp.br/textos/hemeroteca/nor/nor0032/nor32pg50a56.pdf. Acessado em 5/03/2007, as 22:00 hs.

ARISTÓTELES. Política. Trad. António Campelo Amaral e Carlos de Carvalho Gomes. Edição Bilíngüe. Lisboa: Editora Veja, 1998.

ARISTÓTELES. Ética a Nicômaco. Trad. Leonel Vallandro e Gerd Bornheim. São Paulo: Editora Abril Culturas S/A, 1973. (Os Pensadores) 
CANOTILHO, J. J. Gomes. Direito constitucional e teoria da constituição. 7 ed. Coimbra, Portugal: Livraria Almedina, 2003.

CHAUI, Marilena. Introdução à história da filosofia - dos pré-socráticos a Aristóteles. 2 ed. São Paulo: Companhia das Letras, 2002.

CíCERO. Dos deveres. Trad. Angélica Chiapeta. São Paulo: M artins Fontes, 1999.

DUSO, Giuseppe (org.). 0 poder: história da filosofia política moderna. Trad. Andréa Ciacchi, Líssia da Cruz e Silva e Giuseppe Tosi. Petrópolis, RJ: Vozes, 2005.

JAEGER, Werner. Paidéia. Trad. Artur M. Parreita. São Paulo: Martins Fontes, 2001.

GILSON, Etienne. A filosofia na idade média. Trad. Eduardo Brandão. São Paulo: Martins Fontes, 2001.

HESÍODO. Os trabalhos e os dias. Trad. Mary de Camargo Neves Lafer. 3 ed. São Paulo: Editora lluminuras Ltda, 1996.

HOBBES, Thomas. Leviatã ou matéria, forma e poder de um estado eclesiástico e civil. Trad. João Paulo M onteiro e M aria Beatriz Nizza da Silva. 2 ed. São Paulo: Abril Cultural, 1979. (Os Pensadores)

KELSEN, Hans. Teoria geral do direito e do Estado. Trad. Luís Carlos Borges. São Paulo: Martins Fontes, 2005.

LALANDE, André. Vocabulário técnico e crítico da filosofia. Trad. Fátima Sá Correia e et all. São Paulo: Martins Fontes, 1996.

LOCKE, John. Dois tratados sobre o governo. Trad. Julio Fischer. São Paulo: M artins Fontes, 2001.

M AGEE, Bryan. História da filosofia. Trad. M arcos Bagno. São Paulo: Edições Loyola, 1999.

M ARCHI, Cesare. Grandes pecadores, grandes catedrais. Trad. Píer Luigi Cabra e Mônica Stahel. São Paulo: M artins Fontes, 1991.

M ARX, Karl. Para a crítica da economia política - Do capital. Trad. Edgard Malagodi. São Paulo: Editora Nova Cultural Ltda, 1999. (Coleção Os Pensadores)

PLATÃO. A República. Trad. Enrico Corvisieri. São Paulo: Editora Nova Cultural Ltda, 1999. Coleção Os Pensadores.

REALE, Giovanni. História da filosofia antiga. Vol II. Platão e Aristóteles. Trad. Henrique Cláudio de Vaz Lima e M arcelo Perine. São Paulo: Edições Loyola, 1994. 
ROUSSEAU, J ean-Jacques. Do contrato social. Vol. I. Trad. Lourdes Santos M achado. São Paulo: Nova Cultural Ltda, 1999. (Coleção Os Pensadores)

ROUSSEAU, Jean-Jacques. Discurso sobre a origem e os fundamentos da desigualdade entre os homens. Vol. II. Trad. Lourdes Santos M achado. São Paulo: Nova Cultural Ltda, 1999. (Coleção Os Pensadores)

RUBY, Christian. Introdução à filosofia política. Trad. M aria Leonor F. R. Loureiro. São Paulo: Editora UNESP, 1998.

SIEYĖS, Emmanuel Joseph. A constituinte burguesa. Trad. Norma Azevedo. Rio de Janeiro: Editora Lúmen Júris, 2001.

SKINNER, Quentin. As fundações do pensamento político moderno. Trad. de Renato janine Ribeiro e Laura Teixeira Motta. São Paulo: Companhia das Letras, 1996.

WOLFF, Francis. Sócrates - o sorriso da razão. Trad. Franklin Leopoldo e Silva. 4 ed. São Paulo: Editora Brasiliense, 1987. 